\section{A practical guide to assess the Nancy histological index for UC}

Recently, we published the first validated index to assess histological disease activity in UC. ${ }^{1}$ We believe that some clarifications have to be made regarding the assessment of this index in both clinical practice and clinical trials. Three histological criteria have to be assessed.

The first criterion is the presence of mucosal ulceration defined by the loss of colonic crypts replaced with 'immature' granulation tissue (defined as disorganised blood vessels with extravasated neutrophils) or the presence of fibrinopurulent exudate. The presence of only epithelial stripping should not be considered as ulceration. 'Ulceration' (grade 4 of the Nancy index corresponding to severely active disease) is simply defined by the presence or absence of this criterion on biopsy specimen (figure $1 \mathrm{~A}, \mathrm{~B}$ ).

If ulceration is absent on biopsy specimen, the pathologist has to assess the second histological criteria, which is 'acute inflammatory cells infiltrate'. Acute inflammatory cells infiltrate is defined by the presence of neutrophils in lamina propria and/or epithelial cells, with three grades:

- Moderate to severe: presence of multiple clusters of neutrophils in lamina propria and/or in epithelium that are easily apparent. In this case, it defines grade 3 of the Nancy index (figure 1C).

- Mild: few or rare neutrophils in lamina propria or in the epithelium that are difficult to see. In this case, it defines grade 2 of the Nancy index (figure 1D).

- Absence: no neutrophils on biopsy specimen.

Then, in the absence of neutrophils on biopsy specimen, pathologist has to assess 'chronic inflammatory infiltrate'. Chronic inflammatory infiltrate is defined by the presence of lymphocytes and/or plasmocytes and/or eosinophils in lamina propria. Chronic inflammatory infiltrate has to be assessed by two grades: 

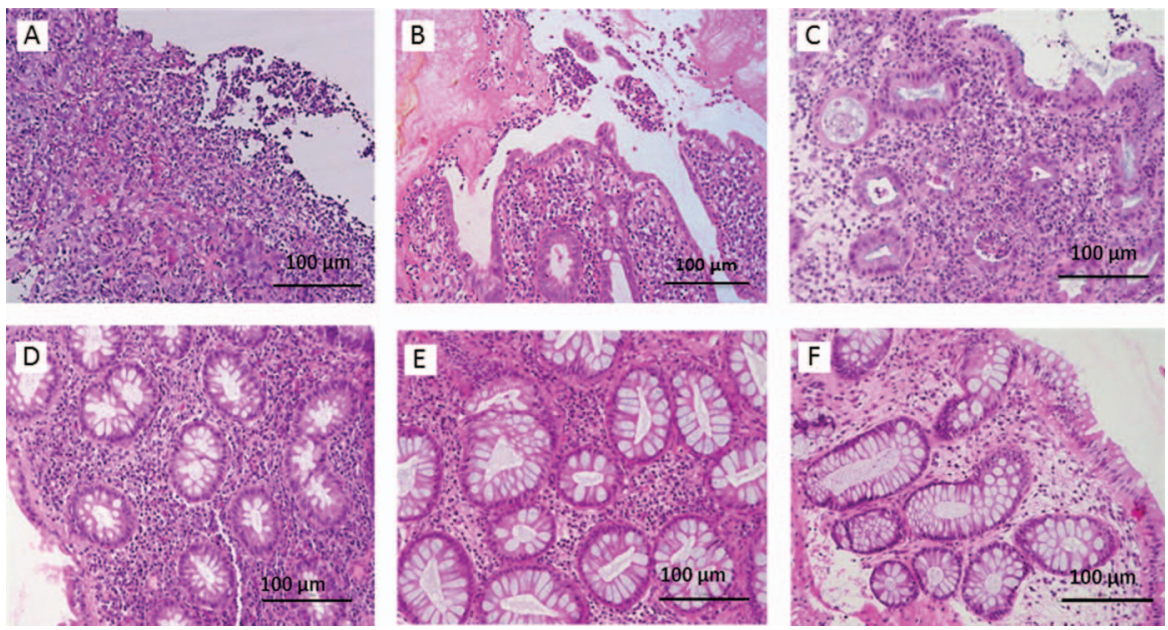

Figure 1 (A) Ulceration of colonic mucosa with inflamed granulation tissue corresponding to grade 4 of the Nancy index (HES $\times 200)$. (B) Ulceration of colonic mucosa with neutrophils in fibrin corresponding to grade 4 of the Nancy index (HES $\times 200$ ). (C) Presence of multiple clusters of neutrophils in lamina propria and/or in epithelium that are easily apparent. Acute inflammatory cells infiltrate is moderate to severe, corresponding to grade 3 of the Nancy index. (HES $\times 200$ ). (D) Presence of few or rare neutrophils in lamina propria or in the epithelium that are difficult to see. Acute inflammatory cells infiltrate is mild, corresponding to grade 2 of the Nancy index (HES $\times 200$ ). (E) Biopsy specimen showing no acute inflammatory cells infiltrate and presence of a moderate-to-severe increase in chronic inflammatory cells number corresponding to grade 1 of the Nancy index (HES $\times 200)$. (F) Biopsy specimen showing a mild increase in chronic inflammatory cell number. In this case, it defines a grade 0 of the Nancy index (HES $\times 200)$. HES, hematoxylineosin-saffron.

- Moderate to severe: presence of an increase in chronic inflammatory cells number that are easily apparent. In this case, it defines a grade 1 of the Nancy index (figure 1E).

- No or mild: no or mild increase in chronic inflammatory cells number. In this case, it defines a grade 0 of the Nancy index (figure 1F).

Aude Marchal-Bressenot, ${ }^{1}$ Alexis Scherl, ${ }^{2}$ Julia Salleron, ${ }^{3}$ Laurent Peyrin-Biroulet ${ }^{4,5}$

${ }^{1}$ Department of Pathology, University of Reims et Champagne-Ardenne, Reims, France
${ }^{2}$ Department of Pathology, Genentech, Inc, South San Francisco, California, USA

${ }^{3}$ Department of biostatistics, Institute de Cancérologie de Lorraine, Vandoeuvre-lès-Nancy, France

${ }^{4}$ Inserm U954, University of Lorraine, Vandoeuvre-lèsNancy, France

${ }^{5}$ Department of Hepato-Gastroenterology, Nancy

University of Hospital, Vandoeuvre-lès-Nancy, France

Correspondence to Professor Laurent Peyrin-Biroulet, Department of Gastroenterology, Inserm U954, Université de Lorraine, Allée du Morvan, Vandœuvrelès-Nancy 54 511, France; peyrinbiroulet@gmail.com

Contributors All authors contributed to editing of the article. AM-B and AS drafted the figure.
Competing interests $L P-B$, consulting fees from Merck, Abbvie, Janssen, Genentech, Mitsubishi, Ferring, Norgine, Tillots, Vifor, Therakos, Pharmacosmos, Pilège, BMS, UCB-pharma, Hospira, Celltrion, Takeda, Biogaran, Boerhinger-Ingelheim, Lilly, Pfizer, HAC-Pharma, Index Pharmaceuticals, Amgen, Sandoz. Lecture fees from Merck, Abbvie, Takeda, Janssen, Takeda, Ferring, Norgine, Tillots, Vifor, Therakos, Mitsubishi, HAC-pharma. IS and AM-B, none. AS is a Genentech employee.

Ethics approval CNIL declaration.

Provenance and peer review Not commissioned; internally peer reviewed.

\section{6 OPEN ACCESS}

Open Access This is an Open Access article distributed in accordance with the Creative Commons Attribution Non Commercial (CC BY-NC 4.0) license, which permits others to distribute, remix, adapt, build upon this work non-commercially, and license their derivative works on different terms, provided the original work is properly cited and the use is noncommercial. See: http://creativecommons.org/licenses/ by-nc/4.0/

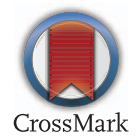

To cite Marchal-Bressenot A, Scherl A, Salleron J, et al. Gut 2016;65:1919-1920.

Received 25 July 2016

Revised 4 August 2016

Accepted 7 August 2016

Published Online First 26 August 2016

Gut 2016;65:1919-1920.

doi:10.1136/gutjnl-2016-312722

\section{REFERENCE}

1 Marchal-Bressenot A, Salleron J, Boulagnon-Rombi C, et al. Development and validation of the Nancy histological index for UC. Gut Published Online First 13 Oct 2015. doi:10.1136/gutjnl-2015-310187 